\title{
SAMORZĄD LOKALNY JAKO BENEFICJENT ŚRODKÓW EUROPEJSKICH
}

\section{LOCAL GOVERNMENT AS A BENEFICIARY OF EU FUNDS}

\section{Streszczenie}

Przystąpienie Polski w 2004 r. do Unii Europejskiej stworzyło szanse dla jednostek samorządu terytorialnego na pozyskanie środków finansowych. Są one obok przedsiębiorców, głównymi beneficjentami środków unijnych alokowanych w ramach krajowych i regionalnych programów operacyjnych. W latach 2007-2013 samorządy miały do dyspozycji ok. 25\% wszystkich środków przeznaczonych dla Polski - 16,6 mld zł, w nowej perspektywie 2014-2020 będzie to niemal 40\% funduszy polityki spójności - 31,28 mld euro. Celem opracowania jest próba dokonania oceny efektywności wykorzystania pozyskiwanych środków europejskich przez jednostki samorządu terytorialnego. Obecnie środki z budżetu UE są jednym z ważniejszych źródeł finansowania zadań i inwestycji, przyczyniając się do poprawy poziomu życia mieszkańców, kształtując rozwój poszczególnych części kraju. Ich wykorzystanie w praktyce przez jednostki samorządu terytorialnego jest w Polsce różne, przy czym powinno szczególną uwagę zwracać się na efektywność wydawanych funduszy tak, aby ograniczyć do minimum liczbę absurdów i projektów, które nie będą miały wpływu na dalszy rozwój Polski. Tym bardziej, że kolejny budżet w perspektywie finansowej 2021-2027 będzie z pewnością dla Polski dużo skromniejszy.

Słowa kluczowe: rozwój lokalny; fundusze Unii Europejskiej; rozwój społeczno-gospodarczy; absorpcja środków europejskich. 


\begin{abstract}
Polish accession to the European Union in 2004 created opportunities for local self-government units to raise additional funds. Entrepreneurs and local self-government units are main beneficiaries of the EU funds allocated under the national and regional operational programs. In 2007-2013 Polish local governments disposed approximately $25 \%$ of all funds earmarked for Poland -16.6 billion Polish zlotys. According to the new financial perspective $2014-2020$ it will be almost $40 \%$ of cohesion policy funds -31.28 billion Polish zlotys. The aim of the study is to assess the effectiveness of using the EU funds obtained by local self-government units. Currently the EU budget is one of the most important sources of financing jobs and investments, so it contributes to the improvement of living standards, shaping the development of the various parts of the country. Special attention should be paid to the effectiveness of the funds in order to minimize number of absurdities and projects that will have no impact on the further development of Poland as the next budget in the financial perspective 2021-2027 certainly will be much more modest for our country.
\end{abstract}

Keywords: local development; EU funds; local government; socio-economic development; absorption of EU funds.

\title{
1. Wprowadzenie
}

Przystąpienie Polski w 2004 r. do Unii Europejskiej stworzyło szanse dla jednostek samorządu terytorialnego na pozyskanie środków finansowych. Są one obok przedsiębiorców, głównymi beneficjentami środków unijnych alokowanych w ramach krajowych i regionalnych programów operacyjnych. W okresie 2007-2015 ${ }^{1}$ na dofinansowanie projektów realizowanych przez te podmioty zarezerwowano ok. $1 / 4$ przyznanych Polsce pieniędzy unijnych ${ }^{2}$. Jednostki samorządu terytorialnego w ramach programów unijnych realizują

1 W perspektywie finansowej 2007-2013 dla pierwszych trzech lat wdrażania programów operacyjnych wprowadzono zasadę $\mathrm{n}+3$. Oznaczało to, że środki, które przyznano Polsce na rok 2007 (rok n) można było wydatkować do roku 2010 (n+3), środki na rok 2009 - do roku 2012, a środki na rok 2010 - do roku 2013. W kolejnych latach (czyli 2011-2013) obowiązywała zasada $n+2$ co oznacza, że ostateczny okres wydatkowania środków zakończył się w 2015 (stąd większość konkursów o dotacje z nowej perspektywy 2014-2020 zostanie ogłoszona w 2016 roku).

2 Jastrzębska M., 2011, Znaczenie bezzwrotnych środków zagranicznych jako źródeł finansowania dziatalności jednostek samorzadu terytorialnego w latach 2004-2010, „Finanse Komunalne", nr 10, s. 18-31. 
działania związane z infrastrukturą transportową, kwestiami społecznymi, edukacją, ochroną środowiska a także e-usługami dążąc do poprawy jakości życia mieszkańców, a tym samym zapewniając rozwój gminie.

Celem opracowania jest dokonanie oceny efektywności wykorzystania pozyskiwanych środków europejskich przez jednostki samorządu terytorialnego. Obecnie środki z budżetu UE są jednym z ważniejszych źródeł finansowania zadań i inwestycji, przyczyniając się do poprawy poziomu życia mieszkańców, kształtując rozwój poszczególnych części kraju.

Analiza literatury przedmiotu oraz obserwacja praktyki gospodarczej pozwoliły sformułować tezę, iż wykorzystanie przez jednostki samorządu terytorialnego środków europejskich w Polsce jest na zróżnicowanym poziomie w zależności od regionu co wynika przede wszystkim z faktu, zapewnienia wymaganego wkładu własnego (właściwego zarządzania finansami) ${ }^{3}$ oraz posiadania odpowiedniej kadry posiadającej umiejętność przygotowania wniosków.

\section{Perspektywa finansowa 2007-2013 podsumowanie - perspektywa 2014-2020 podstawowe założenia}

W kończącym programowaniu funduszy unijnych na lata 2007-2013 dla Polski przewidziano środki w wysokości 67,3 mld euro, z czego około 25\% rozdzielono pomiędzy 16 Regionalnych Programów Operacyjnych ${ }^{4}$. Przekazanie części środków pomocowych na poziom regionalny miało zagwarantować najlepsze ich wykorzystanie, zgodnie z planami rozwojowymi i rzeczywistymi potrzebami każdego regionu ${ }^{5}$.

3 Właściwe planowanie finansowe i inwestycyjne w jednostkach samorządowych umożliwia wykorzystanie środków z Unii Europejskiej wspomagając ograniczone własne możliwości finansowania zadań inwestycyjnych.

4 Cele NSS były realizowane za pomocą programów (tzw. programów operacyjnych), zarządzanych przez Ministerstwo Infrastruktury i Rozwoju, programów regionalnych (tzw. regionalnych programów operacyjnych), zarządzanych przez zarządy poszczególnych województw i projektów wspóffinansowanych ze strony instrumentów strukturalnych, tj.: Program Infrastruktura i Środowisko - EFRR i FS; Program Innowacyjna Gospodarka - EFRR; Program Kapitał Ludzki - EFS; 16 programów regionalnych - EFRR; Program Rozwój Polski Wschodniej - EFRR; Program Pomoc Techniczna - EFRR; Programy Europejskiej Współpracy Terytorialnej - EFRR.

5 W artykule zrezygnowano ze szczegółowych opisów poszczególnych programów, które zostały opisane w dokładny sposób przez M. Mosionek-Schweda, Wykorzystanie funduszy 
Polska gospodarka umiejętnie wykorzystując przyznane środki w okresie 2007-2013 ${ }^{6}$ odniosła wiele korzyści (w ciągu ostatnich 11 lat zrealizowano w Polsce ponad 185 tys. projektów finansowanych ze środków Unii Europejskiej) ${ }^{7}$. Pozwoliło to z pewnością na uniknięcie recesji w gospodarce związanej ze skutkami kryzysu finansowego, który w tym okresie dotknął większość państw UE.

Najważniejsze rzeczowe efekty wykorzystanych funduszy w perspektywie 2007-2013, według danych Ministerstwa Infrastruktury i Rozwoju zaprezentowano w tabeli 1.

Tabela1. Efekty rzeczowe Funduszy Europejskich w perspektywie finansowej 2007-2013 w Polsce (dane na 31 marca 2015 r.).

\section{POPRAWA DOSTĘPNOŚCI TERYTORIALNEJ}

11393 tys. km dróg, w tym:

- Długość wybudowanych/ przebudowanych autostrad i dróg ekspresowych: $1413 \mathrm{~km}$,

- Długość wybudowanych/ przebudowanych dróg krajowych i wojewódzkich: 3170 km,

- Długość wybudowanych/ przebudowanych dróg powiatowych i gminnych: $6868 \mathrm{~km}$,

- Długość wybudowanych/przebudowanych linii kolejowych: $1663 \mathrm{~km}$,

- Liczba zakupionych/zmodernizowanych jednostek taboru komunikacji miejskiej: 2633 szt.

ZRÓWNOWAŻONY ROZWÓJ, EKOLOGIA

- Długość wybudowanej/ zmodernizowanej sieci kanalizacyjnej: $24187 \mathrm{~km}$,

- Długość wybudowanej/ zmodernizowanej sieci wodociągowej: $6883 \mathrm{~km}$,

- Liczba wybudowanych/przebudowanych oczyszczalni ścieków: 499,

- 715 inwestycji w zakresie OZE oraz 1756 inwestycji związane z podnoszeniem efektywności energetycznej i kogeneracji.

\section{INWESTYCJE W KAPITAL LUDZKI}

- liczba utworzonych nowych miejsc pracy w ramach EFRR i FS: 157959 etatów, w tym 4000 etatów badawczych,

- liczba utworzonych nowych miejsc pracy w ramach EFS: 255248 etatów (dane pozyskane z wniosków o płatność).

unijnych przez polskie regiony $w$ programowaniu 2007-2013, „Annales Universitatis Mariae Curie-Skłodowska", Sectio H, Oeconomia, Vol. 46, 2012, 1, s. 95-106.

6 W perspektywie 2007-2013 według danych KSI SIMIK na dzień 7 czerwca 2015 r. podpisano z beneficjentami 106130 umów o dofinansowanie na kwotę 410,5 mld zł wydatków kwalifikowalnych, w tym dofinansowanie w części UE 288,4 mld zł, co stanowi 102,7 proc. alokacji na lata 2007-2013, zob. http://www.funduszeeuropejskie.20072013.gov.pl/ AnalizyRaportyPodsumowania/poziom/Strony/realizacja programow 100515.aspx

$7 \quad 10$ lat w UE - 10 lat z funduszami unijnymi, ,Fundusze Europejskie w Polsce. Biuletyn informacyjny" 2014, nr 34, s. 4-5 i s. 35. 
ICT

- Długość wybudowanej sieci Internetu szerokopasmowego: $55806 \mathrm{~km}$,

- Liczba gospodarstw domowych, które otrzymały dofinansowanie dostępu do Internetu:

214088 ,

- Liczba nowych e-usług: 5834.

$\mathbf{B}+\mathbf{R}+\mathbf{I}$

- Liczba objętych wsparciem ośrodków badawczych: 642,

- Liczba pomysłów innowacyjnych inkubowanych dzięki wsparciu: 2 955,

- Liczba projektów badawczych i rozwojowych w ośrodkach badawczych: 231,

- Liczba utworzonych/ zmodernizowanych laboratoriów: 1878 ,

- Liczba wdrożonych technologii: 3722.

ROZWÓJ PRZEDSIĘBIORCZOŚCI

- Liczba przedsiębiorstw objętych systemem B2B: 28 384,

- Liczba wspartych funduszy pożyczkowych i poręczeniowych: 144,

- Liczba wspartych instytucji otoczenia biznesu: 258,

- Powierzchnia wspartych terenów inwestycyjnych: 15783 ha.

Źródło: Opracowanie własne na podstawie: Wykorzystanie środków UE w ramach Narodowej Strategii Spójności 2007-2013, informacja miesięczna za kwiecień 2015, Ministerstwo Infrastruktury i Rozwoju, Warszawa, maj 2015, s. 5.

Rada Europejska w dniach 7-8 lutego 2013 roku podjęła kluczowe decyzje w sprawie budżetu unijnego na lata 2014-2020. Po zatwierdzeniu ich przez Parlament Europejski Polsce przyznano 72,9 mld euro (w cenach stałych 2011 r.) na realizację polityki spójności. W wyniku przeliczenia cen stałych na bieżące wynegocjowana kwota wzrosła o ok. 13 proc. i wynosi 82,5 mld euro. Dodatkowo, otrzymamy ponad $252 \mathrm{mln}$ euro na wsparcie bezrobotnej młodzieży. Oznacza to, że w najbliższych latach Polska pozostanie największym beneficjentem polityki spójności UE spośród wszystkich państw członkowskich $^{8}$. To więcej niż w poprzedniej perspektywie - 2007-2013. Wówczas było to ok. 68 mld euro.

23 maja 2014 r. Komisja Europejska zatwierdziła Umowę Partnerstwa najważniejszy dokument określający strategię inwestowania nowej puli środków europejskich w naszym kraju. Z budżetu polityki spójności na lata 20142020 Polska otrzyma 82,5 mld euro. Na tę kwotę składają się9:

- ok. 76,9 mld euro dostępnych w programach operacyjnych, w tym ponad $252 \mathrm{mln}$ euro na wsparcie bezrobotnej i nie uczącej się młodzieży,

8 Polska jest największym beneficjentem funduszy unijnych. Jednak kwota wsparcia dla Polski per capita nie jest najwyższa w porównaniu do innych państw członkowskich (wyższa jest m.in. w Czechach, Słowacji, Litwie, Łotwie, Estonii i na Węgrzech).

9 Programowanie perspektywy finansowej 2014-2020 - umowa partnerstwa. 
- ok. $700 \mathrm{mln}$ euro dostępnych w programach Europejskiej Współpracy Terytorialnej,

- 4,1 mld euro na projekty infrastrukturalne o znaczeniu europejskim w obszarze transportu w ramach instrumentu „Łącząc Europę”,

- ok. 473 mln euro z Europejskiego Funduszu Pomocy Najbardziej Potrzebującym (FEAD) na programy, które zapewnią żywność dla osób najbardziej potrzebujących oraz odzież i inne podstawowe artykuły osobom bezdomnym oraz dzieciom $w$ trudnej sytuacji materialnej,

- ok. $287 \mathrm{mln}$ z zarządzanej przez KE, ogólnej puli przeznaczonej na pomoc techniczną,

- ok. 100 mln euro na działania innowacyjne związane z rozwojem obszarów miejskich.

Fundusze europejskie na lata 2014-2020 Polska traktuje jako główne, choć nie jedyne źródło finansowania inwestycji zapewniających dynamiczny, trwały i zrównoważony rozwój. Logika programowania opiera się więc na powiązaniu oczekiwań europejskich odnośnie koncentracji na celach Strategii na rzecz inteligentnego i zrównoważonego rozwoju sprzyjającemu włączeniu społecznemu - Europa 2020 (dalej Strategia Europa 2020) z celami krajowymi wskazanymi w Strategii Rozwoju Kraju 2020 - Aktywne społeczeństwo, konkurencyjna gospodarka, sprawne państwo (SRK 2020), przyjętej przez Radę Ministrów w dniu 25 września 2012 r. oraz zoperacjonalizowanymi w strategiach zintegrowanych. Każe to patrzeć na rozwój Polski szerzej niż tylko w kontekście wykorzystywania funduszy unijnych.

W latach 2014-2020 w Polsce realizowanych będzie na poziomie krajowym 6 programów finansowanych odpowiednio z EFRR, EFS, FS, EFRROW, EFRM oraz programy EWT ${ }^{10}$. Na poziomie regionalnym, podobnie jak w latach 2007-2013, będzie realizowanych 16 RPO. Przyjęta struktura programów opiera się na pozytywnych doświadczeniach z okresu programowania 2007-2013 i jest optymalnie dostosowana do realizacji przyjętych celów przez

10 W latach 2014-2020 fundusze polityki spójności zainwestowane zostaną poprzez 6 krajowych programów operacyjnych (Infrastruktura i Środowisko 27 513,9 mld euro, Inteligentny Rozwój 8 614,1 mld euro, Wiedza Edukacja Rozwój 4 419,3 mld euro, Polska Wschodnia 2 117,2 mld euro, Polska Cyfrowa 2 255,6 mld euro, Pomoc Techniczna 0,7 mld euro oraz programy regionalne województw), w tym jeden ponadregionalny dla województw Polski Wschodniej (lubelskie, podkarpackie, podlaskie, świętokrzyskie, warmińsko-mazurskie). Umowa Partnerstwa jest dla nich punktem odniesienia. Programami krajowymi zarządzać będzie minister właściwy ds. rozwoju regionalnego. 
Umowę Partnerstwa. Bierze ona również pod uwagę zintegrowane podejście tematyczne i terytorialne oraz funkcjonujące zgodnie z polskim porządkiem prawnym mechanizmy wieloszczeblowego zarządzania polityką rozwoju ${ }^{11}$.

Nowa perspektywa 2014-2020 zakłada że, projekty podlegające wsparciu będą musiały odpowiadać dziedzinom najbardziej istotnym w kontekście rozwoju kraju. Zatem dotacje unijne będzie można pozyskać na:

- badania naukowe i ich komercjalizację;

- innowacje i powiązania pomiędzy sferą $\mathrm{B}+\mathrm{R}$ a przedsiębiorstwami;

- kluczowe połączenia drogowe (autostrady, drogi ekspresowe) oraz transport przyjazny środowisku (kolej, komunikacja publiczna);

- cyfryzację kraju (e-usługi administracji, szerokopasmowy dostęp do Internetu);

- zieloną energię (odnawialne źródła energii, efektywność energetyczna);

- aktywizację zawodową i rozwój kapitału społecznego.

Zasadniczym czynnikiem decydującym o wyborze danego projektu do dofinansowania będzie jego wpływ na jak najlepsze wykorzystanie potencjału regionów. Promowane będą także przedsięwzięcia wprowadzające innowacyjne rozwiązania na rynek, z których efektów można korzystać długofalowo. Za rozdysponowanie unijnych środków w większym stopniu odpowiedzialne będą województwa. Znacznie więcej funduszy będzie zarządzanych w ramach Regionalnych Programów Operacyjnych, skoncentrowanych na inwestycjach o zasięgu lokalnym i regionalnym. W latach 2007-2013 samorządy miały do dyspozycji ok. 25\% wszystkich środków przeznaczonych dla Polski - 16,6 mld zł, w nowej perspektywie będzie to niemal $40 \%$ funduszy polityki spójności - 31,28 mld euro. Samorządy terytorialne będą miały zatem większą samodzielność w realizacji założonych przez siebie celów rozwojowych. Warto podkreślić, że Mazowsze, jako pierwsze polskie województwo opuściło kategorię najsłabiej rozwiniętych regionów według klasyfikacji unijnej (został przekroczony poziom $75 \%$ unijnego PKB per capita). W związku z tym budżet dla Mazowsza został skonstruowany nieco odmiennie niż w odniesieniu do pozostałych województw. Jednak z uwagi na fakt, że województwo mazowieckie jest równocześnie regionem bardzo zróżnicowanym pod względem poziomu rozwoju, sposób rozdysponowania funduszy dostosowany będzie do

11 W artykule zrezygnowano ze szczegółowych opisów poszczególnych programów perspektywy 2014-2020, które opisano w sposób dokładny na stronie internetowej Ministerstwa Infrastruktury i Rozwoju https://www.mir.gov.pl/fundusze/fundusze_europejskie_2014_2020/strony/start.aspx. 
istniejących dysproporcji w obrębie Mazowsza i uwzględniać będzie specyficzne potrzeby poszczególnych jego subregionów. Niektóre działania dla województwa mazowieckiego będą więc realizowane w ramach programów krajowych lub odrębnych priorytetów inwestycyjnych. Nowością będzie możliwość wdrażania dwufunduszowych Programów Regionalnych, które pozwolą na realizację zarówno ,projektów miękkich" takich jak np. szkolenia, seminaria (wsparcie z Europejskiego Funduszu Społecznego) oraz „twardych inwestycji” w infrastrukturę (wsparcie z Europejskiego Funduszu Rozwoju Regionalnego). Połączenie finansowania z tych dwóch źródeł umożliwi podejmowanie bardziej kompleksowych i elastycznych działań.

\section{Ocena efektywności wykorzystania pomocy finansowej Unii Europejskiej ${ }^{12}$}

W latach 2004-2012 samorządy lokalne (gminy i miasta na prawach powiatu) na realizację projektów europejskich otrzymały łącznie 45651913 tys. zł. Na pulę tę złożyły się zarówno fundusze unijne, jak i dofinansowanie wkładu własnego z budżetu państwa i innych źródeł. Tak znacząca kwota nie pozostała bez wpływu na strukturę budżetu analizowanych jednostek. Na przestrzeni badanego okresu udział środków europejskich w dochodach ogółem wzrósł z 0,6\% w 2004 r. do 7,5\% w 2012 r. (w przypadku gmin), natomiast $\mathrm{w}$ budżetach miast na prawach powiatów przyrost wyniósł 7,9 p.p. ${ }^{13}$ Jednocześnie systematycznie malała liczba samorządów unikających tej formy wsparcia. Dane zestawione w bazie Moja Polis wykazały istnienie 757 takich jednostek w 2006 r. i jedynie 15 w 2012 r. Co więcej, na przestrzeni lat 2006-2012 spośród 2479 gmin w Polsce tylko jedna ani razu nie skorzystała z omawianego źródła finansowania - była to wieś Kaczory w województwie wielkopolskim. Jednostki samorządu lokalnego charakteryzowały się bardzo zróżnicowaną aktywnością w zakresie wykorzystania analizowanego źródła

12 Szczegółowa ocena została zaprezentowana w raporcie: J. Misiąg, W. Misiąg, M. Tomalak, Ocena efektywności wykorzystania pomocy finansowej Unii Europejskiej jako instrumentu polityki spójności społeczno-gospodarczej oraz poprawy warunków życia, Rzeszów 2013, s. 41-53.

13 M. Wojarska., I. Zabielska, Samorzad lokalny jako beneficjent funduszy unijnych (na przykładzie gmin województwa warmińsko-mazurskiego), [w:] E. Pancer-Cybulska, E. Szostak (red.), Unia Europejska w 10 lat po największym rozszerzeniu, Prace Naukowe Uniwersytetu Ekonomicznego we Wrocławiu, nr 380, Wrocław 2015, s. 267.

218 
finansowania. Różnica pomiędzy maksymalną i minimalną wartością wskaźnika środków z UE i innych programów zagranicznych w przeliczeniu na mieszkańca (średnio za lata 2006-2012) wyniosła 18 836,74 zł. Do rekordzistów, którzy w analizowanym okresie pozyskali najwięcej, należały gminy: Uniejów w województwie łódzkim (18 844,72 zł na mieszkańca) oraz Krynica Morska (18 215,52 zł) i Jastarnia w województwie pomorskim (11 630 zł). Z kolei na drugim końcu szeregu - z najniższymi wartościami wskaźników - znalazły się gminy wiejskie: Sochaczew (16,39zl) i Trojanów w województwie mazowieckim $(13,12 \mathrm{zl})$ oraz Komorniki w województwie wielkopolskim $(7,98 \mathrm{zl})^{14}$.

W zakresie absorpcji środków unijnych w dotychczasowych perspektywach oprócz licznych korzyści uwidoczniły się następujące słabości, które powinny być wyeliminowane, aby w perspektywie finansowej 2014-2020 efektywnie wykorzystać przyznane środki:

1. System absorpcji środków europejskich należy pozbawić charakteru ekstensywnego i mechanicystycznego ${ }^{15}$. Jego funkcją powinno być nie szybkie i efektowne ich wydatkowanie, ale ich mądre wykorzystywanie (efektywne). Mechanizm jest wadliwy z powodu jego zbiurokratyzowania i myślenia o nim jako o narzędziu władzy, a nie rozwoju. Prowadzi to do tego, że inwestuje się w przedsięwzięcia doraźne i przypadkowe i często zbędne, przy czym nikt nie myśli czy w przyszłości stać go będzie na utrzymanie wybudowanych obiektów ${ }^{16}$.

14 Tamże, s. 267.

15 Wykształciliśmy w sobie jako społeczeństwo przeświadczenie, że najważniejsze jest to, żeby wydać te pieniądze. Ministerstwo nakazuje, aby je wydawać mądrze, ale kluczowe jest to, że pierwszym priorytetem jest je po prostu wydać. Natomiast kolejność powinna być odwrotna tzn. nas powinna obchodzić perspektywa rozwojowa, a nie perspektywa finansowa.

16 Powyższy problem nie dotyczy tylko Polski. W każdym kraju UE można znaleźć projekty absurdalne, które nie powinny uzyskać dofinansowania np.: Stok narciarski na duńskiej wyspie Bornholm został wybrany do współfinansowania z Europejskiego Funduszu Rolnego na rzecz Rozwoju Obszarów Wiejskich przez władze Danii. Farmer Ole uwielbia jeździć na nartach. Za pieniądze z Unii Europejskiej zbudował dwa stoki narciarskie, a że na Bornholmie śnieg pada bardzo rzadko, kupił też armatkę śnieżną. Trasa jest otwarta tylko kilka tygodni w roku. Korzysta z niej nie więcej niż 10 osób dziennie. Jak to możliwe, że Unia podarowała duńskiemu farmerowi 100 tysięcy euro? „Der Spiegel” umieścił lidzbarski projekt na liście ,euroabsurdów, bo wody termalne, które będą zasilać baseny mają zbyt niską temperaturę. Trzeba będzie ją podgrzewać. W efekcie gmina ma wydawać rocznie 800 tys. zł na jej podgrzewanie. Budowa zespołu basenów wraz obiektami towarzyszącymi pochłonie $96 \mathrm{mln}$ zł, z tego $64 \mathrm{mln}$ zł to fundusze unijne”, zob. ,, Euroabsurd”, 
2. Patrząc na mapę Polski z perspektywy rozwojowej, łatwo dostrzec, że mamy do czynienia z postępującą dywergencją. Jej dynamika jest w pewnym stopniu osłabiana przez dostępność środków unijnych. Trzeba jednak pamiętać, że w przyszłości ich skala będzie stopniowo ograniczana. Ponadto fakt, że jakieś terytorium teraz korzysta z napływu publicznych pieniędzy zewnętrznych nie musi wcale prowadzić do zwiększenia jego potencjału rozwojowego i podniesienia instytucjonalnej zdolności jego efektywnego wykorzystania. Przeciwnie, należy przyjąć, że znaczący napływ środków europejskich przykrywa rzeczywiste słabości wielu gmin i powiatów, a zarazem nie zachęca do wysiłku na rzecz ich przełamania. I w tym sensie pieniądze europejskie pomagają doraźnie, koniunkturalnie (np. zmniejszają bezrobocie), ale szkodzą długofalowo, strukturalnie ${ }^{17}$. Wiele samorządów zdecydowało się, na wykorzystanie maksymalnej puli środków unijnych stając się ich zakładnikami. Można postawić pytanie: kto będzie utrzymywał deficytowe stadiony, lotniska czy inne inwestycje, które nigdy by nie powstały, gdyby były finansowane pieniędzmi ,zarobionymi”, a nie darowanymi?. Czy będą możliwości zapewnienia środków w budżecie na utrzymanie funkcjonowania przedsięwzięcia w przyszłości po zakończeniu projektu?. Łatwe pieniądze rozleniwiają i uzależniają. To największy problem z wykorzystaniem unijnych dotacji. Gminnych urzędników - jak zauważają autorzy raportu „Kurs na innowacje” przygotowanego przez zespół pod kierownictwem prof. Jerzego Hausnera - nadal rozlicza się często nie z jakości projektów dofinansowywanych z unijnej kasy, lecz $\mathrm{z}$ ich liczby.

3. Przefinansowanie województw Polski Wschodniej ${ }^{18}$.Znacząca część środków przeznaczonych na inwestycje infrastrukturalne została skierowana do województw słabiej rozwiniętych, charakteryzujących się względnie niskim poziomem rozwoju. Preferowane przy podziale środków strukturalnych były więc województwa słabsze, z niskim poziomem PKB na jednego

czyli ,zimne termy”. Ministerstwo żąda wyjaśnień - Lidzbark Warmiński, http://lidzbarkwarminski.wm.pl/148170,Euroabsurd-czyli-zimne-termy-Ministerstwo-zada-wyjasnien. html. Podobnych projektów z wykorzystaniem unijnych dotacji, które niewiele przyniosły w Polsce zrealizowano wiele - patrz S. Krawiec, Mapa euroabsurdów, „Wprost”, 2013, nr 9 (1566), s. 68.

17 J. Hausner i in., Narastajace dysfunkcje, zasadnicze dylematy, konieczne dzialania. Raport o stanie samorzadności terytorialnej w Polsce, Kraków 2013, s. 75.

18 J. Misiąg, W. Misiąg, M. Tomalak, Ocena efektywności wykorzystania pomocy finansowej..., s. 49-50. 
mieszkańca, wysokim bezrobociem i na ogół słabą infrastrukturą. Wydaje się, że w województwach tych środki unijne zostały w dużej części skierowane na uzupełnienie katastrofalnych luk w podstawowej infrastrukturze komunalnej i transportowej - budowano wodociągi i kanalizację, oczyszczalnie ścieków, budowano i modernizowano drogi lokalne, wzmocniono infrastrukturę telekomunikacyjną (telefonia, Internet), budowano i modernizowano budynki użyteczności publicznej. Były to inwestycje niewątpliwie potrzebne i poprawiające zarówno poziom życia mieszkańców, jak i warunki dla działalności gospodarczej. Te lepsze warunki nie przełożyły się jednak na przyspieszenie wzrostu gospodarczego ${ }^{19}$. Podstawowej przyczyny tego faktu upatrywać należy w zbytniej koncentracji działań na problemach infrastruktury, przy zaniedbaniu innych czynników zwiększających atrakcyjność regionu jako miejsca lokowania nowych inwestycji produkcyjnych i miejsca podejmowania działalności produkcyjnej i usługowej. Tak więc działania na rzecz infrastruktury nie przyniosły zakładanych efektów ze względu na brak niezbędnych działań uzupełniających. Ważnym czynnikiem powodującym niską ocenę efektywności inwestycji infrastrukturalnych jest też na pewno zawyżanie kosztów niektórych inwestycji . Dotyczy to zwłaszcza inwestycji drogowych, i kolejowych. Tak więc znaczące preferencje, przyznane przy podziale środków unijnych województwom Polski Wschodniej nie dały zakładanego przyspieszenia wzrostu gospodarczego.

4. Środki unijne, zgodnie z zasadą dodatkowości, stanowić mają dopełnienie środków finansowych, którymi dysponują władze publiczne, przedsiębiorcy i organizacje. Budowanie wizji rozwojowych ignorujących tę kwestię to kosztowna iluzja prowadząca do osłabienia endogenicznych czynników i mechanizmów rozwojowych oraz uzależnienia od zewnętrznych środków finansowych. Oczywiście, środki z funduszy stanowią bezzwrotną pomoc, ale ich przyznanie uwarunkowane jest spełnianiem przez beneficjenta wielu kryteriów określonych przez Unię Europejską. Powinno pamiętać się, że działa tu zasada dodatkowości (uzupełnienia) i efekt dźwigni, bowiem zadaniem środków z programów pomocowych nie jest zastępowanie krajowych funduszy i środków własnych, lecz dofinansowanie tych działań, które zwiększą konkurencyjność oraz dobrobyt ekonomiczny i rozwój

19 Województwa, np: śląskie i małopolskie, które - mimo relatywnie małego zasilania środkami unijnymi - osiągnęły tempo wzrostu gospodarczego wyższe od tempa wzrostu całej gospodarki. 
społeczny zarówno w skali regionu, jak i państwa członkowskiego, a w rezultacie przyczynią się do umocnienia Wspólnoty Europejskiej.

5. Należy znacząco ograniczyć liczbę oraz uprościć treści regulacji biurokratycznych warunkujących wykorzystanie środków europejskich. Ich liczba czynią pozyskiwanie tych środków przedsięwzięciem kosztownym oraz potencjalnie ryzykownym dla ich beneficjentów. Po wejściu do Unii pojawiła się strategia: „Zwal wszystko na Brukselę" - zwiększając biurokrację. Tworzy się niepotrzebnie skomplikowane przepisy, które zabezpieczają urzędników przed podejmowaniem decyzji i odpowiedzialnością. „Bo Unia tego wymaga" - tłumaczy urzędnik konieczność wypełniania tabelki czy dodatkowych dokumentów, która jest czysto polskim innowacyjnym wkładem.

6. Przez dostępność środków z Brukseli zabrakło zachęt do reform i zwiększenia efektywności polskiej administracji publicznej. Przez to polskie urzędy działają uznaniowo, nieefektywnie. Gdyby nie środki unijne, pogarszająca się sytuacja ekonomiczna wymusiłaby głębokie reformy administracji państwowej już kilka lat temu. Napływ funduszy z UE pozwolił jednak zamaskować rosnącą nieefektywność polskiego systemu politycznego i mimo jego wad osiągać wzrost gospodarczy. Od 2004 roku zatrudnienie w administracji publicznej wzrosło o 100 tysięcy osób, to też wpływ środków unijnych.

7. Formalizm i złożoność procedur aplikacyjnych. Należy tu przede wszystkim wymienić zbyt krótkie terminy składania wniosków oraz trudności $\mathrm{z}$ wypełnieniem aplikacji o wsparcie i wymaganej do niego dokumentacji. Przedsiębiorstwa miały dużą trudność z poprawnym złożeniem dokumentów. Wnioski aplikacyjne są zbytnio rozbudowane, dodatkowo wymagana jest ogromna liczba załączników, których pozyskanie jest często kwestią kilku a nawet kilkunastu miesięcy. Dodatkową trudność sprawia również fakt częstych zmian dokumentacji konkursowej, w tym zmian ogłaszanych terminów konkursów, wytycznych dla wnioskodawców, instrukcji wypełniania wniosków itp., niezrozumiały, trudny i nieprzystępny język pisania dokumentów, co często utrudnia interpretację zawartych zapisów $^{20}$. Rodzi to konieczność korzystania na etapie aplikowania z usług

20 W 2011 roku Urząd Marszałkowski w Toruniu pięć razy przesuwał konkurs na unijne dotacje dla firm $w$ ramach poddziałania 5.2.1. Wsparcie inwestycji mikroprzedsiębiorstw (Nr RPOWKP 75/V/5.2.1/2011). Pierwotnie miał zostać ogłoszony w lutym $2011 \mathrm{r}$. natomiast ostatecznie nabór wniosków został przeprowadzony w dniach 09.01.2012 r. 
firm konsultingowych, które są drogie i nie dają gwarancji otrzymania pieniędzy stąd wielu podmiotów nie stać na skorzystanie z takiej możliwości. Należy także zaznaczyć, iż na etapie oceny, zwłaszcza formalnej wniosku, występuje znaczny formalizm i biurokracja ze strony urzędników, która powoduje, iż poprawki dotyczą często nieistotnych kwestii, co wpływa na wydłużenie samej procedury oceny i generuje dodatkowe koszty, bądź skutkuje wręcz odrzuceniem wniosku (kryteria formalne na poziomie regionalnym są zbyt rozbudowane, skoncentrowane wokół wymogów o charakterze biurokratycznym, dodatkowo podlegają uszczegółowieniom na listach sprawdzających, co powoduje, że system oceny formalnej staje się nieprzejrzysty i skomplikowany np. kujawsko pomorskie - 31 stronnicowa tabela opisująca kryteria formalne). Należy także zaznaczyć, iż czas jaki upływa od złożenia dokumentacji konkursowej do uzyskania informacji o pozytywnej ocenie projektu jest dość długi (wynosi od kilku miesięcy do nawet 1 roku). Należy znacząco wzmocnić po stronie administracji publicznej, szczególnie tej określanej jako „funduszowa”, przekonanie o jej służebności, a nie jej zwierzchności wobec obywateli, organizacji i podmiotów gospodarczych.

8. Należy odrzucić naganną praktykę ,zmiany reguł gry w trakcie jej trwania". W szczególności odnosi się to do zaleceń instytucji zarządzających programami współfinansowanymi ze środków europejskich, zmieniających warunki formalno-finansowe realizowanych projektów. Dla przykładu w październiku 2009 r. Urząd Marszałkowski w Toruniu ogłosił konkurs, w którym przyznawał przedsiębiorcom milionowe dotacje na inwestycje z unijnego Regionalnego Programu Operacyjnego (RPO). Zgłosiło się ponad 600 firm, ocena aplikacji ciągnęła się miesiącami, a pieniędzy nie starczyło dla wszystkich, którzy spełnili kryteria formalne i merytoryczne. Dopiero 7 kwietnia 2011 roku - a więc blisko półtora roku po ogłoszeniu konkursu - 19 przedsiębiorców dowiedziało się, że dostanie dofinansowanie. Na dodatek Instytucja Zarządzająca RPO czyli Urząd Marszałkowski przed podpisaniem ostatecznej umowy poinformowała ich, iż dopuszcza wniesienie zabezpieczenia wyłącznie w formie hipoteki bądź gwarancji bankowej czego wcześniej nie było w dokumentacji konkursowej. Zmiana sposobu przyznawania dotacji już po tym, jak wnioskodawcy przeszli

- 20.01.2012 r., J. Hołub, Ciuciubabka z unijnymi dotacjami hamuje rozwój, „Gazeta Wyborcza" z dnia 15.09.2011 r. 
wielomiesięczną ocenę, jest zwyczajnie nieeleganckie, o braku przejrzystości procedur nie wspominając ${ }^{21}$.

9. Zasady doboru ekspertów oceniających wnioski stanowiły często pole do nadużyć. Związane jest to z niewystarczającymi, jak się wydaje, zabezpieczeniami eliminującymi ewentualny konflikt interesów, jaki ma miejsce w przypadku występowania osób w podwójnej roli: jako wspierającego wnioskodawcę w procesie przygotowywania wniosku oraz eksperta właściwej komisji oceniającej. Brak mechanizmów wykluczających takie patologiczne sytuacje prowadziły do tego, że dotacje uzyskiwały niekoniecznie najlepsze projekty.

10. Unijne dotacje nie wpłynęły ożywczo na rozwój innowacyjności polskich przedsiębiorstw. Uzyskiwane przez polskie firmy środki finansowe z dotacji w znakomitej większości zostały przeznaczane na zakup gotowych, zachodnich technologii. W praktyce więc tylko korzystają z najnowszych rozwiązań, stając się ich konsumentami. W ten sposób nie tylko uzależniają się od know-how wielkich koncernów, ale w istocie napędzają rozwój gospodarek krajów zamożnych. Tymczasem warunkiem rozwoju innowacyjności jest inwestowanie we własne wynalazki i wdrożenia nowych rozwiązań do produkcji. Tylko wówczas przedsiębiorstwa mogą zdobywać przewagę konkurencyjną, oferować swoje produkty drożej nie tylko we własnym kraju, ale i za granicą. Za nowatorskie, nieznane wcześniej rozwiązania klienci są w stanie więcej zapłacić, co powoduje, że bogaci się zarówno firma, jak i krajowa gospodarka. W istocie więc Polska nadal pozostaje wielkim rynkiem zbytu dla zamożnych państw Unii Europejskiej. Ponadto zabrakło determinacji, aby - przekazując środki beneficjentom - oczekiwać powiązania ich projektów z rozwojem gospodarczym. Nie udało się dotąd stworzyć skutecznego mechanizmu, dzięki któremu odbywałby się realny transfer badań naukowych do polskiej gospodarki. Brak innowacji w polskich przedsiębiorstwach ogranicza ich konkurencyjność i prowadzi do stagnacji gospodarki ${ }^{22}$. Firmy muszą być innowacyjne, aby liczyć się

21 T. Ciechoński, Straszny unijny konkurs dla firm. Marszatek zmienia zasady dotowania, „Gazeta Wyborcza” z dnia 14.06.2011 r.

22 Polska osiągając syntetyczny wskaźnik innowacyjności na poziomie 0,313 znalazła się wśród krajów o umiarkowanej innowacyjności, określanej jako moderate innovators wyprzedzając Rumunię $(0,204)$, Bułgarię $(0,229)$, Lotwę $(0,272)$ i Litwę $(0,283)$. W porównaniu z wynikiem z poprzedniego roku, Polska utrzymała się w grupie umiarkowanych innowatorów, a dodatkowo przesunęła się o jedno miejsce wyżej wyprzedzając Litwę. 
W świecie, bo schemat niskie płace, niskie koszty i tani produkt przestaje działać. W związku z tym w nowej perspektywie na lata 2014-2020 bardzo ważne będą działania zmierzające do wzrostu innowacyjności i konkurencyjności polskiej gospodarki ${ }^{23}$.

11. Należy zapewnić, aby udział własny samorządu w realizacji zadań dofinansowywanych ze środków UE był w większości finansowany z nadwyżek operacyjnych budżetu, a nie z komercyjnych kredytów, które doprowadzają do nadmiernego zadłużenia ${ }^{24}$. Jednostka samorządu terytorialnego, która nie generuje nadwyżki operacyjnej, a chce zapewnić wkład własny do projektów inwestycyjnych zmuszona jest sprzedać swój majątek, albo sięgać po instrumenty rynku dłużnego. Jeśli stan taki utrzymuje się w okresie kilku lat, może zostać zagrożona płynność finansowa JST.

Należy mieć nadzieję, że po wyciągnięciu stosownych wniosków i wyeliminowaniu powstałych niedociągnięć Polska odniesie również sukces w perspektywie 2014-2020.

\section{Podsumowanie}

1 maja 2004 r. Polska stała się członkiem Unii Europejskiej i od tego momentu polskie regiony otrzymały ogromną szansę modernizacji gospodarki oraz rozwoju kapitału ludzkiego. Środki te mogą przyczynić się do przyspieszenia rozwoju społeczno-gospodarczego gmin, poprawy standardu świadczenia usług publicznych oraz stanu środowiska naturalnego i dziedzictwa kulturowego, a w konsekwencji do podwyższenia poziomu życia mieszkańców i stworzenia lepszych warunków do prowadzenia tam działalności gospodarczej.

Nie należy jednak popadać w zbyt wielki optymizm. Polska prezentuje wskaźniki poniżej średniej UE w większości kategorii. (Innovation Union Scoreboard 2015). Wprawdzie w latach 2006-2013 Polska zanotowała wzrost wskaźnika innowacyjności SII (średnio rocznie $0,9 \%$ ), ale wzrost ten był wolniejszy niż wzrost tego wskaźnika dla całej UE (średnio rocznie 1,7\%) więc luka innowacyjna między Polską a UE się powiększyła.

23 Tokarski A., Tokarski M., Barriers and Benefits of Financing projects with European Funds by micro, small and medium-sized enterprises (MSMEs) in Poland, ,Journal of Management and Financial Sciences (JMFS)" Warsaw School of Economics, Collegium of Management and Finance, Volume VIII, Issue 21 (September 2015), s. 102.

24 Powyższą problematykę omawia szerzej J. Ciak, Nierównowaga fiskalna sektora samorzadowego w Polsce w latach 2009-2013, [w:] J. Wantoch-Rekowski (red.), Samorzad terytorialny w Polsce. Uwagi de lege lata i de lege ferenda, Włocławek 2015, s. 139-148. 
Z możliwości tej gminy korzystały w różnym zakresie - od sporadycznej realizacji kilku projektów po sytuację, w której udział środków z UE i innych programów zagranicznych w dochodach budżetu ogółem stanowił znaczny odsetek. Fundusze unijne stanowią dla jednostek samorządu terytorialnego szansę na realizację zarówno przedsięwzięć infrastrukturalnych, jak i projektów związanych z rozwojem społeczności lokalnych.

W latach 2014-2020 duża część środków Unii Europejskiej jest przewidziana na wdrażanie krajowych i regionalnych programów operacyjnych $\mathrm{z}$ przeznaczeniem na finansowanie projektów inwestycyjnych. Znaczącym beneficjentem tych środków będą jednostki samorządu terytorialnego (JST), w największym stopniu gminy. Realizują one zadania, których zakres i wartość mają istotne znaczenie zarówno dla społeczeństwa, jak i dla gospodarki danego regionu. Warunkiem pozyskania funduszy unijnych będzie na pewno zdolność jednostek samorządu terytorialnego do generowania wkładu własnego.

Możliwość absorpcji środków z UE przy realizacji projektów unijnych zależy przede wszystkim od zdolności do wygenerowania korzystnej tendencji kształtowania się nadwyżki operacyjnej (w kolejnych latach realizacji projektu, a także jego fazy eksploatacyjnej), rozumianej jako różnica między dochodami bieżącymi, a wydatkami bieżącymi, oraz od zdolności JST do pozyskiwania w odpowiednim czasie i w odpowiedniej wysokości środków pożyczkowych.

Jednostki samorządu terytorialnego funkcjonują w warunkach występowania ilościowej i jakościowej luki infrastrukturalnej. Jej niwelowanie wymagać będzie jeszcze przez długi czas alokacji wysokich nakładów inwestycyjnych. Mając na uwadze ograniczoność środków budżetowych i wysoki poziom zadłużenia wielu samorządów, a także zalecenia Komisji Europejskiej, można przypuszczać, że w nowej pespektywie zwiększy się rola Partnerstwa Publiczno-Prywatnego (PPP) jako formy finansowania kapitałochłonnych inwestycji infrastrukturalnych ${ }^{25}$.

Podsumowując dotychczasowe wykorzystanie środków europejskich przez Polskę należy ocenić pozytywnie. Z dwóch dotychczasowych perspektyw

25 Problematykę PPP omawiają J. Laskowska i R. Musiałkiewicz, Partnerstwo publiczno-prywatne jako forma realizacji zadań gminy, [w:] J. Wantoch-Rekowski (red.), Samorzad terytorialny w Polsce. Uwagi de lege lata..., s. 25-42 a także M. Tokarski, Fundusze europejskie szansa rozwoju partnerstwa publiczno-prywatnego w Polsce, [w:] E. Urbańczyk, M. Romanowska (red.), Zarzqdzanie wartościa przedsiębiorstwa, Zeszyty Naukowe Uniwersytetu Szczecińskiego, nr 686; Finanse. Rynki finansowe. Ubezpieczenia nr 47, Szczecin 2011, s. 561-574. 
unijnych Polska otrzymała 82 mld euro - to ponad 185 tysięcy projektów, z czego 70 tys. zrealizowanych przez przedsiębiorstwa. Po dziesięciu latach członkostwa bilans finansowy między Polską a Unią Europejską jest dla Polski bardzo korzystny. Otrzymywane w tym czasie środki z roku na rok systematycznie rosły. Pieniądze, które Polska otrzymała, przewyższyły sumę wniesionych składek członkowskich ponad trzykrotnie (od 2004 r. do końca marca 2013 r. Polska wpłaciła do unijnego budżetu 28,321 mld euro (z tego 28,18 mld to nasza składka członkowska), a dostała 79,255 mld euro. W rezultacie Polska jest największym beneficjentem netto funduszy Unii Europejskiej ${ }^{26}$.

Rozsądne wykorzystanie środków unijnych stanowi jedno z narzędzi, które może zdecydowanie poprawić sytuację gospodarczą, zwłaszcza na szczeblu lokalnym, oraz przyspieszyć rozwój ekonomiczny.

Należy mieć nadzieję, że po wyciągnięciu stosownych wniosków i wyeliminowaniu powstałych niedociągnięć Polska odniesie również sukces w rozpoczętej perspektywie 2014-2020. Wykorzystując doświadczenia z poprzednich perspektyw powinno szczególną uwagę zwracać się na efektywność wydawanych funduszy tak, aby ograniczyć do minimum liczbę absurdów i projektów, które nie będą miały wpływu na dalszy rozwój Polski. Tym bardziej, że kolejny budżet w perspektywie finansowej 2021-2027 będzie z pewnością dla Polski dużo skromniejszy.

\section{Literatura}

1. 10 lat $w U E-10$ lat $z$ funduszami unijnymi, ,Fundusze Europejskie w Polsce. Biuletyn informacyjny" 2014, nr 34.

2. Ciechoński T., Straszny unijny konkurs dla firm. Marszałek zmienia zasady dotowania, „Gazeta Wyborcza” z dnia 14.06.2011 r.

3. Hausner J. i in., Narastajace dysfunkcje, zasadnicze dylematy, konieczne działania. Raport o stanie samorzadności terytorialnej w Polsce, Uniwersytet Ekonomiczny, Małopolska Szkoła Administracji Publicznej, Kraków 2013.

4. Hołub J., Ciuciubabka z unijnymi dotacjami hamuje rozwój, „Gazeta Wyborcza” z dnia 15.09.2011 r.

5. Jastrzębska M., Znaczenie bezzwrotnych środków zagranicznych jako źródel finansowania działalności jednostek samorzadu terytorialnego w latach 2004-2010, „Finanse Komunalne" 2011, nr 10.

6. Krawiec S., Mapa euroabsurdów, „Wprost” 2013, nr 9 (1566).

$26 \quad 10$ lat $w$ UE - 10 lat z funduszami unijnymi..., s. 4-5, 35. 
7. Laskowska J., Musiałkiewicz R., Partnerstwo publiczno-prywatne jako forma realizacji zadań gminy [w:] J. Wantoch-Rekowski (red.), Samorzad terytorialny w Polsce. Uwagi de lege lata i de lege ferenda, Wydawnictwo PWSZ we Włocławku, Włocławek 2015.

8. Misiąg J., Misiąg W., Tomalak M., Ocena efektywności wykorzystania pomocy finansowej Unii Europejskiej jako instrumentu polityki spójności spoleczno-gospodarczej oraz poprawy warunków życia, Wyższa Szkoła Informatyki i Zarządzania, Rzeszów 2013.

9. Mosionek-Schweda M., Wykorzystanie funduszy unijnych przez polskie regiony w programowaniu 2007-2013, „Annales Universitatis Mariae Curie-Skłodowska”, Sectio H, Oeconomia, Vol. 46 (2012).

10. Pancer-Cybulska E., Szostak E. (red.), Unia Europejska w 10 lat po największym rozszerzeniu, Prace Naukowe Uniwersytetu Ekonomicznego we Wrocławiu, nr 380, Wydawnictwo Uniwersytetu Ekonomicznego we Wrocławiu, Wrocław 2015.

11. Tokarski A., Tokarski M., Barriers and Benefits of Financing projects with European Funds by micro, small and medium-sized enterprises (MSMEs) in Poland, „Journal of Management and Financial Sciences (JMFS)", Warsaw School of Economics, Collegium of Management and Finance, Volume VIII, Issue 21 (September 2015).

12. Tokarski M., Fundusze europejskie szansa rozwoju partnerstwa publiczno-prywatnego $w$ Polsce, [w:] E. Urbańczyk, M. Romanowska (red.), Zarzadzanie wartościa przedsiębiorstwa, „Zeszyty Naukowe Uniwersytetu Szczecińskiego”, nr 686; Finanse. Rynki finansowe. Ubezpieczenia $\mathrm{nr} 47$ Szczecin 2011.

13. Wantoch-Rekowski J. (red.), Samorzad terytorialny w Polsce. Uwagi de lege lata i de lege ferenda, Włocławek 2015.

14. Wykorzystanie środków UE w ramach Narodowej Strategii Spójności 2007-2013, informacja miesięczna za kwiecień 2015, Ministerstwo Infrastruktury i Rozwoju, Warszawa 2015.

Maciej Tokarski

Wyższa Szkoła Bankowa w Toruniu 